DOI: http://dx.doi.org/10.17651/ONOMAST.64.27

Onomastica LXIV, 2020

MICHAŁ MORDAŃ

PL ISSN 0078-4648

https://orcid.org/0000-0002-5709-3469

michal1437@gmail.com

Uniwersytet w Białymstoku

Białystok, Polska

\title{
MIĘDZYNARODOWA KONFERENCJA NAUKOWA „ONOMASTYKA POWOŁŻA” (NOWOGRÓD WIELKI, 17-20.09.2019)
}

W dniach 17-20 września 2019 r. w Rosji odbyła się XVII Międzynarodowa Konferencja Naukowa „Onomastyka Powołża” („Ономастика Поволжья”). Gospodarzem konferencji był Uniwersytet Państwowy im. Jarosława Mądrego w Nowogrodzie Wielkim.

W sympozjum wzięło czynny udział ponad 100 badaczy z kilkudziesięciu ośrodków naukowych z całej Federacji Rosyjskiej, a także z Algierii, Azerbejdżanu, Białorusi, Kazachstanu, Mołdawii, Polski, Serbii, Słowenii, Turcji, Ukrainy.

Problematyka konferencji, wzorem lat poprzednich, dotyczyła szerokiego spektrum zagadnień onomastycznych. Tematyka wystąpień oscylowała wokół następujących obszarów: teoria i metodologia badań onomastycznych, źródła materiału onomastycznego, toponimia i mikrotoponimia regionalna, antroponimia historyczna i współczesna, urbanonimia i ergonimia, peryferyjne działy onomastyki, onomastyka literacka, onomastyka w dydaktyce szkolnej i akademickiej.

Uroczystego otwarcia konferencji dokonali: p.o. Rektor Uniwersytetu w Nowogrodzie Wielkim J.S. Borowikow, prorektor ds. nauki i innowacji A.B. Jefremienkow oraz dyrektor Instytutu Humanistycznego J.W. Toporowa. Uczestników powitali: stały członek komitetu naukowego konferencji W.I. Suprun oraz przewodniczący komitetu organizacyjnego tegorocznej edycji W.L. Wasiljew.

Obrady toczyły się w ramach dwóch sesji plenarnych i siedmiu posiedzeń w sekcjach. Wykłady plenarne zaprezentowano w pierwszym dniu konferencji. Uczestnicy mieli okazję wysłuchać ośmiu wystąpień: „Onomastyka funkcjonalna i asocjacyjna” (W.I. Suprun, Wołgograd), „Emotywność jako element nominacji hodonimów” (A.M. Miezienko, Witebsk), „Prawosławny onomastykon w języku i językoznawstwie serbskim” (R. Lewuszkina, Belgrad), „Ergonimia konotacyjna” (I.W. Kriukowa, Wołgograd), „Nominacja miejskich obiektów topograficznych i problemy ekspertyzy nowych nazw” (M.W. Gołomidowa, Jekaterynburg), , «Wielkie dwory» — dziedzictwo nowogrodzkie w ojkonimii Karelii” (I.I. Mułłonen, Pietrozawodsk), „Kształtowanie się mikrosystemów toponimicznych (na materiale hydronimii historycznej ziemi nowogrodzko-pskowskiej)” (W.Ł. Wasiljew, N.N. Wichrowa, Nowogród Wielki), „Mikrotoponimia w aspekcie projekcji semantycznej” (L.A. Klimkowa, Arzamas).

W drugim dniu konferencji odbyły się obrady panelowe. Sekcja 1. dotyczyła aspektów historyczno-etymologicznych toponimii regionalnej. Prelegenci omówili następujące zagadnienia: toponimy Karelii w aspekcie arealnym, wpływy lapońskie na toponimię europejskiej części północnej Rosji, stratyfikacja toponimii przedsłowiańskiej na obszarze między Wołgą, Dźwiną i Dnieprem, etymologia toponimów Kolezija (Колезия) і Rezija (Резия), toponimia Nowogrodu Wielkiego w dokumentach z XII-XV w. i jej lokalizacja na współczesnej mapie miasta, stan badań nad historyczną toponimią Białorusi, terminologia geograficzna i krajobrazowa na tle toponimii, nazwy Kijowa w źródłach staroruskich, toponimy w kontekście związków rosyjskich z Rzecząpospolitą w II poł. XVII w. Część referatów dotyczyła analizy wybranych toponimów okolic Orenburga, północnej Rosji, Krymu i ziemi samarskiej. W kręgu zainteresowań badaczy znalazły się również modele słowotwórcze i elementy ugrofińskie w hydronimii Czuwaszji, etymologia hydronimu Wiaźma oraz kulturowy aspekt choronimów okolic Kostromy. 
Sekcja 2. poświęcona była źródłom i metodom w badaniach toponomastycznych. Prelegenci w swoich wystąpieniach zwrócili uwagę na: leksykograficzne aspekty toponimii, mikrotoponimię Traktu Jekatieryńskiego (Екатерининский тракт) na Białorusi, nazwy pastwisk jako przykład mikrotoponimii lokalnej (na materiale z okolic Kostromy). Podjęto również tematykę hydronimów obwodu woroneskiego. Dwie prezentacje były poświęcone ojkonimii: pierwsza dotyczyła okolic miasta Wołżsk w Republice Mari El, druga zaś — południa Ukrainy. Kolejne referaty poświęcono toponimom w przygotowywanym słowniku frazeologicznym rosyjskich gwar ludowych (Полный фразеологический словарь русских народных говоров), sposobom analizy dokumentów do badań nad toponimią Karelii (I poł. XX w.) i onimom republiki Komi (przełom XIX i XX w.). Zaprezentowano również aktualny stan prac nad stworzeniem bazy danych Toponimia Rosji oraz najnowsze kierunki badań w zakresie onimii Chanty-Mansyjskiego Okręgu Autonomicznego. Zwrócono ponadto uwagę na problem ortografii toponimów złożonych (w zakresie użycia małych i wielkich liter).

Tematyka panelu 3. oscylowała wokół zagadnień urbanonimii i ergonimii. W tej sekcji poruszono takie problemy jak: zależność między nazwami oficjalnymi, półoficjalnymi i nieoficjalnymi w urbanonimii, urbanonimy o pozbawionej podstaw motywacji (na przykładzie miasta Uljanowsk), nazwy miejsc — punktów orientacyjnych w przestrzeni miejskiej. Troje badaczy poddało analizie semantyczno-strukturalnej urbanonimy Tyraspola, Uglicza i Nieriechty. Uczestnicy konferencji wysłuchali też wystąpień traktujących o wartościach społecznych w ergonimii, kulturowym dziedzictwie utrwalonym w ergonimach Białorusi i Francji, ergonimach w branży turystycznej, ergourbonimach dziecięcych w aspekcie porównawczym (na materiale rosyjskim i chińskim). Prelegenci przedstawili również referaty dotyczące nazw cerkwi i klasztorów w mieście Torżok w pespektywie historycznej oraz nazw organizacji związanych z rekreacją. Omówiono również kwestię lingwistycznego słownika urbanonimów, zastosowania słowników toponimii miejskiej w kształceniu przyszłych pedagogów, wykorzystania onimów w dydaktyce obcokrajowców oraz założeń przedmiotu podstawy onomastyki na studiach pedagogicznych.

Przedmiotem zainteresowania w sekcji 4. była antroponimia w wymiarze historycznym i współczesnym. Wystąpienia prelegentów dotyczyły: motywacji wyboru imion książąt staroruskich, imion w prawosławnym dyskursie religijnym, tradycji nazewniczych rodu Bakuninów, problemów adaptacji w języku rosyjskim imion obcych, imiennictwa dzieci w rodzinach mieszanych w Ałma-Acie (z uwzględnieniem rodzin tatarskich), nowych imion w antroponimii Tatarów, nazwisk pochodzenia tureckiego w języku rosyjskim i bułgarskim pochodnych od nazw zawodów, antroponimii ksiąg podatkowych (ревизских сказок) Imperium Rosyjskiego jako źródła w badaniach rosyjskiego systemu nazwisk, nazwisk odimiennych z formantem - $u k /-c z u k$ na pograniczu polsko-białoruskim w końcu XIX w., ,pseudonazwisk” w świecie sportu, przezwisk we współczesnej komunikacji językowej, przezwisk metaforycznych związanych z wyglądem człowieka. W dwóch wystąpieniach poruszono kwestię związków onomastyki i dialektologii: pierwsze dotyczyło imion w gwarach okolic Kostromy, drugie zaś - antroponimii Jakucji w kontekście dialektologii.

Referaty wygłoszone w sekcji 5. (Teoria i metody badań onomastycznych) były poświęcone następującym zagadnieniom: markery onomastyczne w przestrzeni kulturowej (na przykładzie Smoleńska), nazwy własne w przestrzeni wirtualnej, antroponimy w dyskursie politycznym, sposoby kategoryzacji w toponimii, problemy opisu komponentów narodowo-kulturowych w strukturze ergonimów, historia „poetonimologii”, rola onomastyki w nauce języka rosyjskiego jako obcego na uniwersytecie w Algierze. Należy też odnotować dwa wystąpienia, które dotyczyły terminologii. Badacze scharakteryzowali w nich strukturę przestrzeni onomastycznej wobec kwestii terminologicznych oraz poddali analizie źródła rosyjskiej terminologii onomastycznej i ich umiejscowienie w sferze lingwistyki komputerowej. Uczestnicy konferencji mieli również okazję wysłuchać referatu poświęconego życiu i pracy naukowej A.W. Supieranskiej.

Sekcja 6. poświęcona była zagadnieniom peryferii onomastycznych. W ramach tego panelu przedstawiono tematy związane $\mathrm{z}$ wykorzystaniem przewodników o Wołdze w badaniach onomastycznych obszaru Powołża, nazwami mieszkańców w prasie socjalistycznej, zmianami diachronicznymi w rosyjskiej zoonimii, użyciem zoonimów w kynologii praktycznej, funkcjonowaniem nazw 
własnych zaczerpniętych z Biblii we współczesnym języku rosyjskim, buriackimi nazwami rodów, specyfiką eklezjonimów i ich miejscem w systemie onomastycznym (na przykładzie Białorusi), semantycznym aspektem etnonimów Chajdincy (хайдинцьь) i Jugi (юги), potencjałem komunikacyjnym nazw różnego typu wydarzeń, adresatywną funkcją nazw filmów dla dzieci i młodzieży, chrematonimami w tekstach reklamowych (na materiale nazw zegarków), podejściem interdyscyplinarnym w badaniach szyldów oraz elementami toponimicznymi w nazwach obrazów.

Tematem przewodnim sekcji 7. była onomastyka literacka. Prelegenci skupili się na zagadnieniach takich jak: autobiografizm w onomastyce literackiej, współczesna onomastyka literacka, onimy w metajęzyku (na materiale literatury masowej), antroponimy w literaturze pięknej. Większość wystąpień dotyczyła jednak nazw własnych w twórczości pojedynczych pisarzy i poetów (G. Iwanowa, M. Lermontowa, N. Gumilowa) lub analizy onimów w konkretnych utworach literackich. Przedmiotem uwagi w dwóch referatach były onimy w folklorze (nazwy własne kamieni i skał w legendach japońskich, onomastyka w folklorze Baszkirii).

W ostatnim dniu na posiedzeniu plenarnym dokonano podsumowania konferencji. Przewodniczący poszczególnych sekcji w krótkich wystąpieniach scharakteryzowali zakres poruszanych tematów oraz wskazali elementy dyskusji panelowych, które wymagałyby omówienia w szerszym gronie badaczy-onomastów. Następnie odczytano i przyjęto rezolucję, w której podkreślono wysoki poziom zaprezentowanych referatów, zarówno tych o charakterze teoretycznym, jak też poświęconych analizie synchronicznej i diachronicznej poszczególnych klas onimów. Zwrócono uwagę na konieczność popularyzacji wiedzy z zakresu onomastyki nie tylko w kręgach naukowych, ale również w pracy dydaktycznej w szkołach i na uczelniach wyższych. 